Relations industrielles

Industrial Relations

\title{
FOS in Manitoba. A Rejoinder
}

\section{Errol Black et Jim Silver}

Volume 45, numéro 3, 1990

URI : https://id.erudit.org/iderudit/050611ar

DOI : https://doi.org/10.7202/050611ar

Aller au sommaire du numéro

Éditeur(s)

Département des relations industrielles de l'Université Laval

ISSN

0034-379X (imprimé)

1703-8138 (numérique)

Découvrir la revue

Citer cet article

Black, E. \& Silver, J. (1990). FOS in Manitoba. A Rejoinder. Relations industrielles

/ Industrial Relations, 45(3), 612-615. https://doi.org/10.7202/050611ar
Résumé de l'article

FOS in Manitoba. A Rejoinder
Tous droits réservés (c) Département des relations industrielles de l'Université Laval, 1990
Ce document est protégé par la loi sur le droit d'auteur. L’utilisation des services d'Érudit (y compris la reproduction) est assujettie à sa politique d'utilisation que vous pouvez consulter en ligne.

https://apropos.erudit.org/fr/usagers/politique-dutilisation/ 


\section{DISCUSSION}

\section{FOS in Manitoba. A Rejoinder}

\section{Errol Black and Jim Silver}

In a comment on our article on FOS in Manitoba ${ }^{1}$, Hugh Grant asserts that we «are opposed to the Conservative government's intention to repeal the legislation» (p. 166). He accuses us of promoting FOS as a «panacea for all problems faced by 'smaller bargaining units'» (p. 167), and of treating the principle of free collective bargaining in a cavalier fashion (p. 168).

It seems to us that Grant has mis-read our article. We started by arguing that from labour's point of view, the likely repeal of FOS «[...] is a gain in that a flawed piece of legislation is about to be removed». We immediately added: «But it is a loss in that the problem at which the legislation was directed remains unresolved" (p. 146). We concluded by saying that the flaws of FOS «are sufficiently dangerous to the trade union movement that its death at the hands of a Conservative [...] government would almost certainly be beneficial to organized labour». Again, we immediately added: "Yet the demise of FOS will leave unresolved the problem at which the legislation was aimed [...]» (p. 163).

Our position, which we think we stated clearly, is that FOS is a flawed piece of legislation, and labour is better off without it. Grant's apparent misreading of our position may have arisen because we did not leave the matter at explaining our opposition to FOS. We tried to explain why FOS found such widespread support within the labour movement, and we even went so far as to suggest that «[...] the case made for FOS by those unions which promoted and supported it is more compelling than some of its critics have allowed» (p. 155). Their case does not convince us, but we can understand and appreciate why so many unions supported FOS.

The fact is that, its flaws notwithstanding, FOS is aimed at a real need, namely, the problems of workers in weak bargaining units; i.e., bargaining units where the threat of strike action involves low or even zero costs for the employer, because of the employer's ability to replace striking workers and maintain production and sales. In these circumstances, workers are reluctant to join unions because they see little prospect for tangible gains. As well, many of these workers fear employer reprisals (despite the fact that such reprisals are explicitly outlawed under the Manitoba Labour Relations

* Silver, Jim, Department of Political Science, University of Winnipeg, and Errol BLACK, Department of Economics, Brandon University, Brandon, Manitoba.

1 See Jim Silver and Errol BLACK, «Contradictions and Limitations of Final Offer Selection: The Manitoba Experience», and Hugh GRANT, «A Comment» in Relations Industrielles/Industrial Relations, vol. 45, no. 1, 1990, pp. 146-165 and 166-168. 
$A c t$ ). The vast majority of new jobs being created, we point out, are in such situations. FOS provides such workers with an alternative to strikes which they have little chance of winning. With the repeal of FOS this problem unionising and winning gains for workers in weak bargaining positions will remain. The need at which FOS was aimed will remain unresolved. This is the contradiction cited in our title: FOS is a flawed instrument aimed at a real need; it should be withdrawn because of its flaws, but that leaves the need unmet.

Grant makes some additional comments. First, he asserts that we «ignore the overwhelming fact that 22 [of the 42 applications filed in 1988] came from the UFCW/MFCW, and 10 from the IUOE» (p. 166). We were aware of this fact, but didn't and don't consider it overwhelming.

Before we address this point, it may be useful to have the up-to-date statistics on FOS. These are provided in Table 1.

\section{TABLE 1}

\section{Summary Statistics on FOS in Manitoba}

January 1, 1988 to January 30, 1990

Total Applications

Selector decisions filed for union

for employer

Selector appointed, decision pending

Dismissals

Parties reached agreement prior to Selector

appointment/decision or Withdrawn

Awaiting appointment of Selector

Pending (no order/dismissal issued)

Source: Data provided by Janet Duff, Registrar, Manitoba Labour Board.

Of the 72 applications filed under FOS, 30 have come from the MFCW and 17 from IUOE. Another seven involve the UFCW, but four of these came from employers. These statistics are not surprising. The MFCW and the IUOE have many small locals. Thus, of the 24 locals from the MFCW for which data are available the largest had 92 employees. Eleven of the locals had less than 20 . The average size was about 33. In the case of the IUOE, 16 of the 17 applications came from situations involving about five or six workers employed by Rural Municipalities ${ }^{2}$. These numbers are consistent with our observation that the bulk of FOS applications were from

2 A factor deterring strike action by members of these small locals is that the rural municipalities for which they work and in which many of them live are hostile to unions. Moreover, in contrast to their counterparts in the city, if they do strike they are conspicuous and isolated. 
small units. Such units have a hard time organizing, and thus, from labour's perspective, have a need for some form of legislative assistance.

Grant notes (apparently with approval) that the then-Conservative opposition referred to the FOS legislation as the «bail-out Bernie bill» (p. 166). Bernard Christophe does play an aggressive and influential role in the MFL. But two things should be noted. First, his MFCW is particularly active in organizing, and very frequently in the kinds of small workplaces where organizing is made especially difficult by virtue of the disproportionate power of the employers. Therefore it should not come as a surprise that he supports FOS. Second, it has to be acknowledged, irrespective of where one stands on this issue, that the majority of unions - and not just MFCW - supported FOS, including major unions such as the Steelworkers and the MGEA ${ }^{3}$. What is more, when the Tory government announced its intention to repeal FOS all unions - including the unions who had originally opposed the legislation - united to oppose such action. This solidarity reflects a concern in the labour movement that repeal of FOS will simply be the first in a series of measures aimed at weakening the Labour Relations $A c t$ and undermining the position of unions ${ }^{4}$. It is worth noting, as well, that unions have been actively joined in the fight to prevent repeal of FOS by the Manitoba Action Committee on the Status of Women.

Secondly, Grant notes that «FOS [...] is not intended to replace, but rather approximate, the perceived bargaining strengths of the two parties» (p. 167). We have no quarrel with this observation; indeed, the criteria set out in the legislation requires that selectors take into account the relevant factors that shape a particular bargaining relationship. However, such criteria are subject to interpretation and weighting, which will vary from selector to selector and situation to situation. Therefore, selector decisions are not entirely predictable, and it is this unpredictability which could result in gains - even if modest gains - for weak unions faced with a choice between capitulation or a suicidal strike ${ }^{5}$.

Finally, Grant argues that we treat in a cavalier fashion the impact of FOS on «free collective bargaining». Grant does not define the principle of "free collective bargaining», but he seems to be implying that free collective

3 It is interesting to note that at the lást MFL convention in October 1989, there was the first ever election for president in the history of the organization (since 1956). The two main candidates were Susan Hart-Kulbaba, a full-time employee of the MFL and a strong proponent of FOS, and Paul Moist, a CUPE representative and one of the most vigorous opponents of FOS. Susan Hart-Kulbaba won the election.

4 This concern was forcefully expressed in the brief by the Brandon \& District Labour Council to the Law Amendments Committee (February 22, 1990): «[...] Why is it so critical to repeal F.O.S. after just two years? Is it because the legislation is working? Is it because the Conservative/Liberal business interests feel that they could more easily break unions without this legislation? Is it because the Conservative/Liberal Party does not want to represent the interests of working men and women but only the wealthy business interests?» (p. 3).

5 We would also point out that, if our argument about the purposes of FOS is correct, the legislation should be evaluated not just in relation to the outcomes of the FOS process itself, but also in relation to the capacity of trade unions to organize and sustain unions in small establishments in industries which currently have low union penetration rates. 
bargaining is what we had in Manitoba prior to the introduction of FOS. We won't attempt a definition here, but we would note that in the Canadian context it is a principle that seems to have been taking quite a battering in recent years ${ }^{6}$. In the late 1970's the MFL campaign for anti-scab legislation was condemned on the grounds it would undermine «free collective bargaining». Dick Martin, the then-president of the MFL, countered the opposition by pointing out some of the facts of life of free collective bargaining. Amongst other things, he noted that when workers were locked out it was against the law for them to go into their workplaces and continue to produce and sell the output. However, when workers went on strike it was legal for employers to replace them and continue production. Moreover, local police forces were called in to guarantee replacement workers' safe passage through the picket lines, and, in some cases, the courts issued injunctions imposing severe restrictions on picketing and related activities. Martin went on to argue that when these things were coupled with restrictions on strikes established in labour relations acts and the use by governments of fiscal and monetary policies to keep unemployment high, it seemed clear that whatever the concept of free collective bargaining meant, it did not have much to do with the freedom of workers. We share this perspective.

\section{Postscript}

Yogi Berra's dictum, "It's never over till it's over", has received some empirical support from the Manitoba experience with the FOS game. Contrary to expectations, the bill to repeal FOS was defeated in the Manitoba Legislature on March 14, 1990. From the outset, the Liberal caucus was firm on its support of the Tory bill to repeal FOS. However, the legislative committee hearings on the bill apparently convinced the Liberal caucus either that FOS had some positive features or that support for repeal would cost it votes, because on March 14 the Liberal labour critic on the committee moved an amendment to the bill. The amendment had two features. First, it extended the life of FOS to December 31, 1990. And secondly, it required that a detailed study of the effects of FOS be carried out by June 30, 1991. With NDP support the amendment carried. Then the NDP voted with the Tory caucus in the legislature to defeat the amended bill. This means that FOS (and perhaps other aspects of the Labour Relations Act) will be a key issue in the next Manitoba election. 